
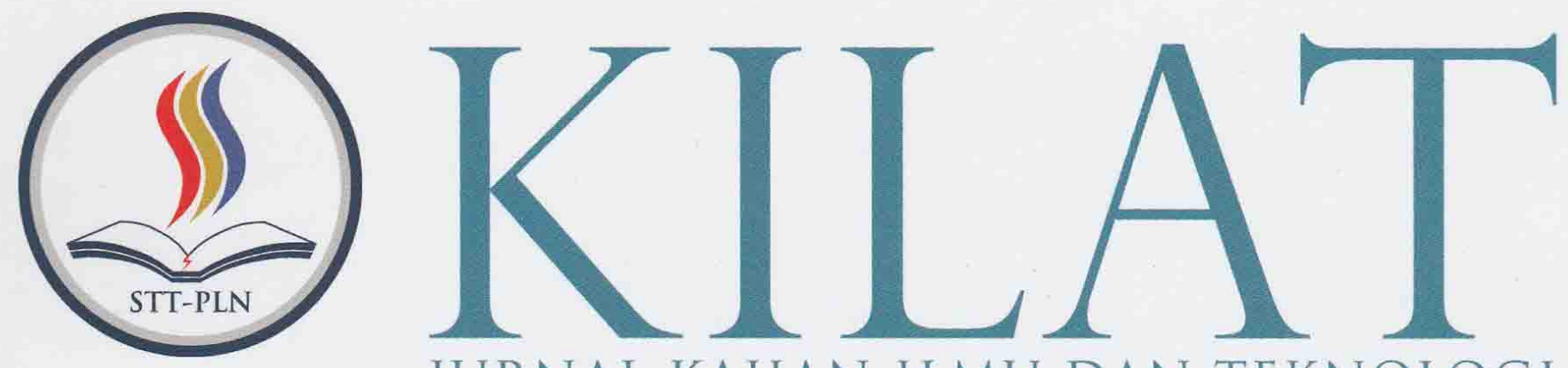
JURNAL KAJIAN ILMU DAN TEKNOLOGI

Dine Tiara Kusuma:

M. Yoga Distra Sudirman: Yessy Fitriani

Emillia; Yuliansyah

Rosida Nur Aziza; Dhzillan Dzhalila

Ranti Hidayawanti

Dewi Arianti Wulandari; Hendra Jatnika; Yudhy S. Purwanto

Rr. Mekar Ageng Kinasti; Endah Lestari; Devita Mayasari

Faisal Piliang

Mauludi Manfaluthy

Pauzi Hasan; Peby Wahyu Purnawan

Rahmi Amir: Baginda Oloan Lubis

Sabar Hanadwiputra; Subandri

Ndaru Ruseno; Satria
PENDEKATAN METODE ALTMAN Z-SCORE DALAM PENENTUAN INSENTIF BONUS PEGAWAI

METODE YURIDIS PENGELOLAAN SAMPAH RUMAH TANGGA DAN SAMPAH SEJENIS DI STT-PLN

METODE KUANTITATIF DENGAN PENDEKATAN KLASIK PADA APLIKASI ANALISIS BUTIR SOAL SEBAGAI MEDIA EVALUASI PENENTUAN SOAL YANG BERKUALITAS

UPAYA TERTIB LISTRIK TERHADAP INSTALATIR KABEL DI DAERAH PADAT PENDUDUK (STUDY KASUS KEC. TAMBORA)

RANCANG BANGUN APLIKASI CLUSTERING DATA MINING MENGGUNAKAN METODE K-MEANS DAN K-MODES

POTENSI PEMANFAATAN LIMBAH PEMBAKARAN BATUBARA (BOTTOM ASH) PADA PLTU SEBAGAI MEDIA TANAM DALAM UPAYA MENGURANGI PENCEMARAN LINGKUNGAN

PEMILIHAN PERANGKAT LUNAK PEMINDAHAN BERKAS DALAM MENINGKATKAN PEMANFAATAN TELEPON PINTAR

PEMANFAATAN RADIASI ENERGI TEGANGAN 150 KV UNTUK LAMPU LED PENERANGAN JALAN

KAJIAN PERBANDINGAN PERFORMANSI ROUTING PROTOCOL RIPNG, OSPFV3 DAN EIGRPVG PADA JARINGAN IPV6

PERANCANGAN PROGRAM PENGELOLAAN DATA KEUANGAN PASIEN RAWAT JALAN BPJS PADA RUMAH SAKIT GRAHA JUANDA BEKASI

ANALISA DAN IMPLEMENTASI VTP DENGAN ETHERCHANNEL TYPE LACP

PENGEMBANGAN RANCANG BANGUN SISTEM KESISWAAN DENGAN MENGGUNAKAN FRAMEWORK MVC

(MODEL VIEW CONTROLLER)

\begin{tabular}{|l|l|l|l|l|l|}
\hline KILAT & VOL.7 & NO.1 & HAL. 1 - 90 & APRIL 2018 & ISSN 2089 - 1245 \\
\hline
\end{tabular}




\title{
METODE KUANTITATIF DENGAN PENDEKATAN KLASIK PADA APLIKASI ANALISIS BUTIR SOAL SEBAGAI MEDIA EVALUASI PENENTUAN SOAL YANG BERKUALITAS
}

\author{
Rosida Nur Aziza ${ }^{1}$; Dhzillan Dzhalila ${ }^{2}$ \\ (rosida@sttpln.ac.id) \\ ${ }^{1}$ Dosen Program Studi Teknik Informatika STT-PLN \\ 2 Alumnus Program Studi Teknik Informatika STT-PLN
}

\begin{abstract}
This paper discusses the design of an application for the analysis on items using quantitative method with the classical approach as a media evaluation for teachers in determining the quality of questions in an exam or a test. The classical approach is the process of examining each item in the test based on the students' answers for calculating the Difficulty Index (Dif I) and the Discrimination Index (DI) of each question. The Difficulty Index is the ratio between the number of students who answered an item (or a question) correctly and the total number of students who participated in the test. The Discrimination Index is a measure of how well an item (or a question) is able to distinguish between clever students and students who are less clever. The data used in this research was obtained from class VII SMPN 10 (Junior High School) Makassar, especially on math (subject). The data includes math questions that have been tested, the answers given by the students of class VII, and the data about the students. The results of the item analysis will provide information whether a question can be accepted, corrected or to be rejected. The application generated from this research is expected to be able to offer assistance for the teacher in performing item analysis. The results of the analysis can be used to help teachers in compiling more qualified questions in the future.
\end{abstract}

Keywords: item analysis, quantitative, classical approach, degree of difficulty, differentiating power

\begin{abstract}
Abstrak
Penulisan ini membahas tentang perancangan aplikasi analisis butir soal menggunakan metode kuantitatif dengan pendekatan klasik sebagai media evaluasi bagi guru dalam menentukan soal yang berkualitas. Pendekatan klasik merupakan proses penelaahan butir-butir soal melalui analisis dari jawaban-jawaban siswa dengan menghitung tingkat kesukaran dan daya pembeda tiap soal. Tingkat kesukaran merupakan rasio atau perbandingan antara jumlah penjawab soal dengan benar dan banyaknya total penjawab soal. Sedangkan daya pembeda adalah kemampuan suatu soal untuk membedakan antara siswa yang pandai dengan siswa yang kurang pandai. Data yang digunakan dalam penelitian ini berupa data soal mata pelajaran matematika kelas VII di SMPN 10 Makassar, data siswa, dan data jawaban siswa yang diperoleh dari soal-soal yang telah diujikan. Hasil dari analisis butir soal akan memberikan informasi kepada guru apakah suatu soal dapat diterima, diperbaiki atau harus ditolak. Aplikasi yang dihasilkan dari penelitian ini diharapkan dapat membantu guru dalam melakukan analisis butir soal. Hasil analisis tersebut dapat digunakan untuk membantu kemampuan guru dalam menyusun soal-soal yang berkualitas.
\end{abstract}

Kata Kunci: Analisis Butir Soal, Kuantitatif, Pendekatan Klasik, Tingkat Kesukaran, Daya Pembeda

\section{Pendahuluan}

\subsection{Latar Belakang}

Kegiatan menganalisis butir soal merupakan suatu kegiatan yang harus dilakukan guru untuk meningkatkan mutu soal yang telah ditulis. Kegiatan ini meliputi proses pengumpulan, peringkasan, dan penggunaan informasi dari jawaban siswa untuk membuat keputusan tentang setiap penilaian butir soal. Analisis butir soal secara kuantitatif dengan pendekatan klasik adalah proses penelaahan butir soal melalui informasi dari jawaban peserta tes guna meningkatkan mutu butir soal yang bersangkutan dengan menggunakan teori klasik. Ada beberapa aspek yang perlu diperhatikan dalam analisis butir dengan pendekatan klasik, antara lain Tingkat Kesukaran (TK) dan Daya Pembeda (DP) dari tiap butir soal. Salah satu tujuan dilakukannya analisis adalah untuk meningkatkan kualitas soal, yaitu apakah suatu soal dapat diterima karena telah didukung oleh data statistik yang memadai, diperbaiki karena terbukti terdapat beberapa kelemahan atau tidak digunakan (ditolak) .

Berikut ini adalah beberapa penelitian yang berkaitan dengan analisis butir soal. Suatu penelitian di MAN X Yogyakarta membahas tentang perhitungan analisis butir soal secara manual terhadap tingkat kesukaran butir soal, daya pembeda butir soal, reliabilitas soal, validitas soal, dan fungsi pengecoh butir soal. Tindak lanjut terhadap analisis butir soal dalam penelitian ini adalah perbaikan butir soal yang disesuaikan dengan faktor penyebab buruknya kualitas soal tersebut. Hasil tindak lanjut terhadap butir soal yang sudah layak diterima akan didata dan disimpan di bagian evaluasi untuk selanjutnya dapat digunakan 
sebagai referensi untuk menyusun soal UAS tahun selanjutnya (Pamilu, 2014). Sedangkan riset lain di Grobogan, Jawa Tengah, melaksanakan analisis butir soal berdasarkan validitas soal, reliabilitas soal, tingkat kesukaran, daya pembeda, dan efektifitas pengecoh. Setelah dilakukan analisis, penulis memberikan saran supaya guru melakukan uji coba dan analisis soal serta mempertahankan penyusunan soal yang berkualitas dengan berpedoman pada langkah pengembangan soal sesuai standar (Ariyana, 2011).

Satu riset di Malaysia mencoba mengembangkan suatu perangkat lunak, yang disebut SuperSeTIA, dan mengevaluasi tanggapan pengguna terhadap efektivits perangkat lunak tersebut. SupereTIA merupakan hasil riset gabungan dari Universiti Teknologi MARA, Universiti Utara Malaysia, dan Content Capital Sendirian Berhad untuk membantu pengajar atau guru melakukan pengujian kualitas soal tes (Fook, et.al., 2014). Sedangkan penelitian lain di India mencoba melakukan analisis butir soal pada soalsoal pilihan ganda yang diujikan di Fakultas Kedokteran Ahmedabad (Gajjar et al, 2014). Analisis dilakukan pada 148 mahasiswa setelah 40 jam masa kuliah dalam 1 semester. Kesimpulan dari studi tersebut menunjukkan bahwa pemilihan soal pilihan ganda yang berkualitas akan dapat menilai tingkat pemahaman mahasiswa dengan baik.

\subsection{Tujuan}

Berdasarkan beberapa sumber di atas, dapat disimpulkan bahwa analisis butir soal merupakan bagian penting dari pendidikan, yaitu sebagai salah satu sarana evaluasi kegiatan belajar mengajar. Begitu juga di SMP Negeri 10 Makassar, pelaksanaan analisis butir soal merupakan kewajiban semua guru. Namun sampai saat ini banyak guru belum mampu melakukan kegiatan analisis butir soal tersebut. Hal ini disebabkan karena keterbatasan kemampuan guru serta kerumitan dalam melakukan analisis butir soal secara manual. Berdasarkan latar belakang tersebut, maka penulis merancang suatu aplikasi untuk mempermudah pelaksanaan analisis butir soal. Adapun bahasa pemrograman yang digunakan untuk membangun aplikasi ini adalah PHP.

\subsection{Tinjauan Pustaka}

\subsubsection{Analisis Butir Soal}

Analisis butir soal merupakan kegiatan evaluasi yang dilakukan guru terhadap hasil pelaksanaan suatu tes untuk mengetahui apakah soal-soal (items) yang diberikan memiliki kualitas yang baik. Kegiatan ini meliputi proses pengumpulan, peringkasan dan penggunaan informasi dari jawaban siswa untuk membuat keputusan tentang penilaian (Nitko, 1996). Tujuan penelaahan adalah untuk mengkaji dan menelaah butir soal agar diperoleh soal yang bermutu. Disamping itu, tujuan analisis butir soal juga untuk membantu meningkatkan tes melalui revisi atau membuang soal-soal yang tidak efektif, serta untuk mengetahui informasi diagnostik pada siswa apakah mereka sudah paham mengenai materi yang telah diajarkan (Aiken, 1994). Soal yang bermutu adalah soal yang dapat memberikan informasi setepat-tepatnya sesuai dengan tujuannya, antara lain dapat menentukan peserta didik mana yang sudah atau belum menguasai materi yang diajarkan guru.

\subsubsection{Analisis Kualitatif dan Kuantitatif}

Dalam melaksanakan analisis butir soal, para penulis soal atau guru dapat menganalisis secara kualitatif, dalam kaitan dengan isi dan bentuknya dan kuantitatif dalam kaitan dengan ciri-ciri statistiknya (Anastasi \& Urbina, 1997). Analisis kualitatif mencakup pertimbangan validitas isi dan konstruk, sedangkan analisis kuantitatif mencakup pengukuran kesulitan butir soal dan diskriminasi soal yang termasuk validitas soal dan reliabilitasnya. Definisi yang lebih rinci adalah sebagai berikut:

a. Analisis Butir Soal Secara Kualitatif

Pada prinsipnya analisis butir soal secara kualitatif dilaksanakan berdasarkan kaidah penulisan soal (tes tertulis, perbuatan dan sikap). Penelaahan ini biasanya dilakukan sebelum soal digunakan/diujikan. Aspek yang diperhatikan didalam penelaahan secara kulitatif ini adalah setiap soal ditelaah dari segi materi, konstruksi, bahasa/budaya dan kunci jawaban/ pedoman penilaiannya.

b. Analisis Butir Soal Secara Kuantitatif

Penelaahan soal secara kuantitatif adalah penelaahan butir soal didasarkan pada data empirik dari butir soal yang bersangkutan. Data empirik ini diperoleh dari soal yang telah diujikan. Ada dua pendekatan dalam analisis secara kuantitatif, yaitu pendekatan klasik dan modern. Analisis butir soal secara klasik adalah proses penelaahan melalui informasi dari jawaban peserta didik menggunakan teori tes klasik. Sedangkan pendekatan modern adalah penelaahan butir soal dengan menggunakan Item Response Theory (IRT) atau teori jawaban butir soal. Teori ini merupakan suatu teori yang menggunakan fungsi matematika untuk menghubungkan antara peluang menjawab benar dengan kemampuan peserta didik.

\subsubsection{Analisis Kuantitatif dengan Pendekatan Klasik}

Aspek yang perlu diperhatikan dalam analisis butir soal secara klasik adalah:

a. Tingkat Kesukaran (TK)

Tingkat kesukaran soal adalah peluang untuk menjawab benar suatu soal pada tingkat kemampuan tertentu yang biasanya dinyatakan dalam bentuk indeks. Indeks tingkat kesukaran ini pada umumnya dinyatakan dalam bentuk rasio yang nilainya berkisar antara $0,00-1,00$ (Aiken, 1994). Semakin besar indeks tingkat kesukaran yang diperoleh dari hasil perhitungan, berarti butir soal tersebut semakin mudah. Suatu soal memilliki TK=0,00 artinya tidak ada siswa yang menjawab benar dan bila memiliki TK=1,00 artinya bahwa semua siswa menjawab benar. Skor rata-rata yang diperoleh peserta didik pada butir soal yang 
bersangkutan dinamakan tingkat kesukaran butir soal tersebut. Rumus untuk menentukan Tingkat Kesukaran adalah sebagai berikut (Nitko, 1996):

$$
T K=\frac{\text { Jumlah siswa yang menjawab benar butir soal }}{\text { Jumlah siswa yang mengikuti tes }}
$$

Klasifikasi tingkat kesukaran soal adalah seperti berikut ini:

a. $\quad 0,00<\mathrm{TK}<=0,30$; tergolong sukar

b. $\quad 0,30<\mathrm{TK}<=0,70$; soal tergolong sedang

c. TK $>0,70$; soal tergolong mudah

\section{b. Daya Pembeda}

Daya pembeda soal adalah kemampuan suatu butir soal dapat membedakan antara siswa belajar/siswa yang tidak/kurang/belum menguasai materi yang ditanyakan. Berdasarkan indeks daya pembeda, dapat diketahui apakah suatu butir soal itu baik, perlu direvisi, atau ditolak. Semakin tinggi indeks daya pembeda soal berarti semakin mampu soal yang bersangkutan membedakan siswa yang telah memahami materi dengan siswa yang belum memahami materi. Indeks daya pembeda berkisar antara $-1,00$ sampai dengan $+1,00$. Semakin tinggi daya pembeda suatu soal, maka semakin kuat/baik soal itu. Jika daya pembeda negatif $(<0)$, berarti lebih banyak kelompok bawah (siswa yang tidak memahami materi) menjawab benar dibanding dengan kelompok atas (siswa yang memahami materi yang diajarkan guru). Untuk mengetahui daya pembeda soal bentuk pilihan ganda adalah menggunakan rumus berikut ini :

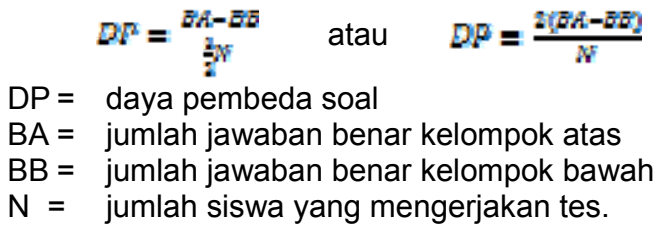

Adapun klasifikasi dari DP adalah seperti berikut ini (Crocker \& Algina, 1986):

a. $\quad 0,40-1,00$; soal diterima baik

b. $\quad 0,30-0,39$; soal diterima perlu diperbaiki

c. $\quad 0,20-0,29$; soal diperbaiki

d. $\quad 0,19-0,00$; soal tidak dipakai/dibuang

Berdasarkan wawancara dengan SMP Negeri 10 Makassar, klasifikasi daya pembeda yang digunakan adalah:

a. $\quad \mathrm{DP}>0,25$; soal diterima

b. $0<\mathrm{DP}<=0,25$; soal direvisi

c. $\mathrm{DP}<=0$; soal ditolak.

\section{c. Penyebaran Jawaban (Distribusi)}

Penyebaran pilihan jawaban djadikan dasar dalam penelaahan soal. Hal ini dimaksudkan untuk mengetahui berfungsi tidaknya jawaban yang tersedia. Suatu pilihan jawaban (pengecoh) dapat dikatakan berfungsi apabila soal pengecoh tersebut: a. Paling tidak dipilih oleh 5\% siswa.

b. Lebih banyak dipilih oleh kelompok siswa yang belum paham mengenai materi yang diujikan.

\section{d. Reliabilitas Skor Tes}

Tujuan utama menghitung reliabilitas skor tes adalah untuk mengetahui tingkat ketepatan dan keajegan skor tes. Indeks reabilitas berkisar $0-1$. Semakin tinggi tingkat koefisien reliabilitas suatu tes (mendekati 1), makin tinggi pula keajegan/ ketepatannya.

\section{e. Reliabilitas Instrumen Tes}

Untuk mengetahui koefisian reliabilitas tes soal bentuk pilihan ganda digunakan rumus Kuder Richadson 20 (KR-20) seperti berikut ini:

$$
K R-20=\frac{k}{k-1}\left[1-\frac{E \psi\left(1-\psi^{2}\right)}{\left.(G)^{2}\right)^{2}}\right]
$$

$\mathrm{k}=$ jumlah butir soal

$(\mathrm{SD})=$ varian .

\subsubsection{Evaluasi}

Secara harfiah kata evaluasi berasal dari bahasa inggris evaluation yang berarti penilaian atau penaksiran. Menurut istilah, evaluasi merupakan kegiatan yang terencana untuk mengetahui keadaan suatu objek dengan menggunakan instrumen dan hasilnya dibandingkan dengan tolok ukur untuk memperoleh kesimpulan.

Dalam siklus pembelajaran, hal pertama yang harus dilakukan guru adalah menyusun rencana mengajar. Hal yang harus dipertimbangkan meliputi rincian kompetensi yang harus dicapai siswa, indikator pencapaian kompetensi dan yang lain sebagainya. Setelah rencana mengajar tersusun dengan baik, guru melakukan kegiatan belajar mengajar sesuai rencana tersebut. Hal yang paling penting untuk diperhatikan dalam proses belajar mengajar ini adalah adanya interaksi yang efektif antara guru, siswa, dan sumber belajar lainnya sehingga menjamin terjadinya pengalaman belajar yang mengarah ke penguasaan kompetensi oleh siswa. Untuk mengetahui dengan pasti ketercapaian kompetensi, guru harus melakukan penilaian secara terarah. Penilaian harus digunakan sebagai proses untuk mengukur dan menentukan tingkat ketercapaian kompetensi dan mengukur efektifitas proses belajar mengajar.

\section{Metodologi Penelitian}

\subsection{Tahapan Pembuatan Aplikasi}

Pengembangan aplikasi didasarkan pada metode Waterfall, yang terdiri dari: analisis kebutuhan, perancangan sistem, pembuatan kode program, pengujian dan implementasi perangkat lunak. Adapu tahapan yang dilakukan dalam penelitian ini ditunjukkan oleh gambar 1 dengan penjelasan sebagai berikut:

\section{a. Identifikasi masalah}

Identifikasi masalah merupakan tahap awal dari penelitian ini. Guru-guru pada SMP Negeri 10 Makassar mengalami kesulitan dalam melakukan analisis butir soal secara manual. Adapun kegiatan ini merupakan kewajiban dan harus dilakukan secara berkala. 


\section{b. Pengumpulan data}

Pengumpulan data dilakukan dengan melakukan observasi langsung ke SMP Negeri 10 Makassar dan melakukan wawancara dengan guru sekolah tersebut. Dari hasil wawancara dengan narasumber diperoleh keterangan bahwa saat ini para guru belum melakukan analisis butir soal disebabkan keterbatasan kemampuan guru.

\section{c. Pengumpulan data}

Pengumpulan data dilakukan dengan melakukan observasi langsung ke SMP Negeri 10 Makassar dan melakukan wawancara dengan guru sekolah tersebut. Dari hasil wawancara dengan narasumber diperoleh keterangan bahwa saat ini para guru belum melakukan analisis butir soal disebabkan keterbatasan kemampuan guru dan kerumitan perhitungan dalam menganalisis butir soal secara manual.

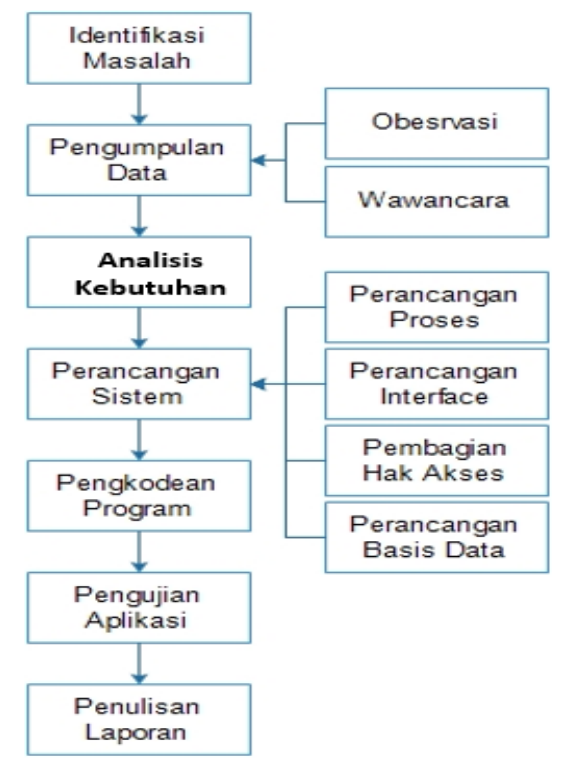

Gambar 1. Tahapan Pembuatan Aplikasi

\section{d. Analisis Kebutuhan}

Melalui wawancara yang telah diperoleh mengenai gambaran umum permasalahan yang dihadapi SMP Negeri 10 Makassar, penulis dapat menentukan kebutuhan untuk rancangan aplikasi analisis butir soal.

\section{e. Perancangan Sistem}

Tahapan ini adalah merancang sistem dengan mempertimbangkan faktor-faktor perma-salahan yang telah ditetapkan pada tahap sebelumnya. Perancangan sistem ini meliputi pembuatan diagram alir aplikasi, perancangan antar muka, pembagian hak akses dan perancangan basis data.

\section{f. Pengkodean Program}

Dalam tahap ini, penulis melakukan proses pengkodean untuk menyusun aplikasi. Bahasa pemrograman yang digunakan adalah PHP.

\section{g. Pengujian Aplikasi}

Pengujian terhadap aplikasi dilakukan untuk mengetahui apakah aplikasi telah sesuai dengan kebutuhan atau masih perlu perbaikan,

\section{h. Penulisan laporan}

Tahapan terakhir yang dilakukan adalah menuliskan laporan hasil penelitian.

\subsection{Perancangan Aplikasi}

\subsubsection{Diagram Alir Aplikasi}

Berdasarkan gambar 2, dapat diketahui bahwa aplikasi yang dirancang memiliki menu utama yang terdiri dari beberapa menu, yaitu: Home, Password, Pengguna, Data, Analisis, Contact, dan Logout. Menu Home berisi penjelasan tentang aplikasi analisis butir soal dan sedikit informasi tentang perhitungan menggunakan pendekatan klasik berupa tingkat kesukaran dan daya pembeda. Menu Password berfungsi untuk mengubah kata kunci pengguna aplikasi. Menu Pengguna hanya dapat dibuka oleh admin dan menampilkan halaman untuk mengelola data pengguna.

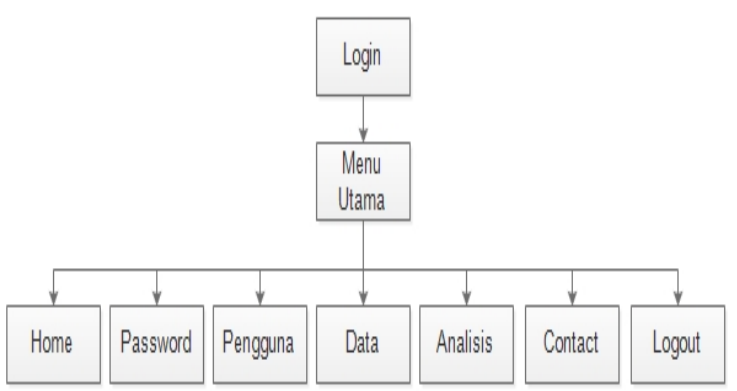

Gambar 2. Hirarki Menu 
Menu Data memiliki beberapa sub menu, yaitu submenu Data Kelas, Data Kompe-tensi, Data Murid, Data Pelajaran, Data Soal, Data Bank Soal. Pengguna berstatus guru yang dapat mengelola sub menu ini. Admin hanya dapat melihat data informasi yang ada, tidak dapat mengelola data. Menu Data ini digunakan guru untuk menambahkan nama siswa, daftar pelajaran, dan soal-soal yang akan dianalisis. Tipe soal yang dapat dianalisis pada aplikasi ini dibatasi untuk soal Pilihan Ganda (PG).

Menu Analisis merupakan menu yang akan menjalankan perhitunganTingkat Kesukaran (TK) dan Daya Pembeda (DP). Guru melakukan pemasukan data jawaban siswa melalui menu Data, kemudian menu ini akan melakukan analisis dan menampilkan hasil soal mana yang akan diterima, direvisi atau ditolak. Hasil dari analisis soal dapat dilihat dan dicetak oleh guru. Kemudian soalsoal yang statusnya diterima secara otomatis akan disimpan dan ditampilkan pada halaman sub menu
Data Bank Soal pada menu Data. Gambar 3 menunjukkan diagram alir dari menu Analisis. Hanya diagram alir pada menu Analisis yang ditampilkan karena bagian ini yang menunjukkan proses perhitungan Tingkat Kesukaran (TK) dan Daya Pembeda (DP) dari tiap butir soal. Adapun keterangan dari Gambar 3 adalah sebagai berikut: sudah = selesai menginput jawaban siswa,

nilai = nilai siswa,

kel_a = kelompok atas,

kel_b = kelompok bawah,

$\mathrm{PA}=$ tingkat kesukaran kelompok atas,

PB = tingkat kesukaran kelompok bawah,

$\mathrm{DP} \quad=$ daya pembeda.

Menu Contact berisi informasi pembuat aplikasi dan alamat atau email yang bisa dihubungi. Jika pihak SMP Negeri 10 Makassar sebagai pengguna aplikasi menemui adanya masalah atau kesulitan dalam menjalankan aplikasi dapat menghubungi kontak tersebut. Menu terakhir adalah

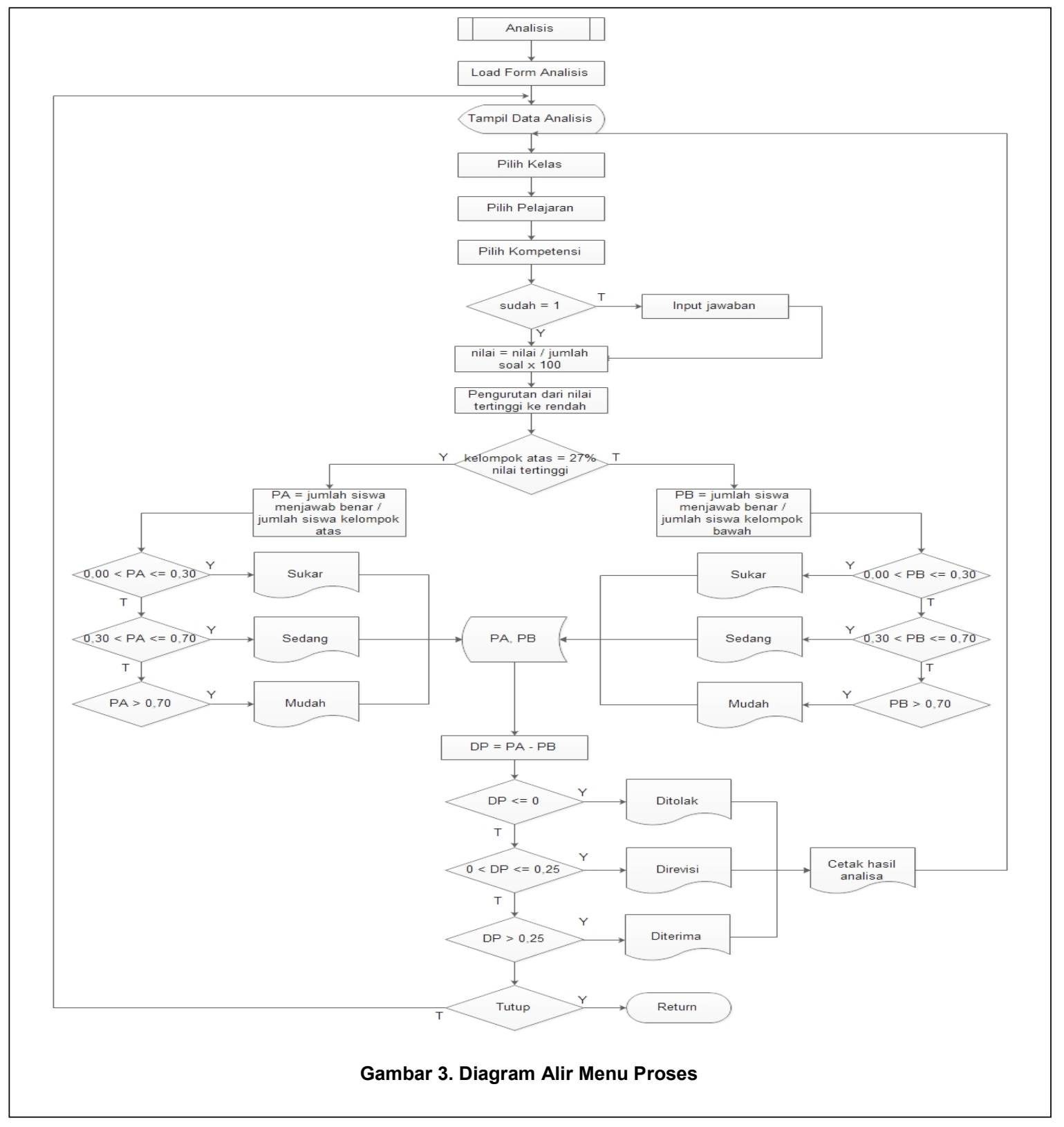


Menu Logout untuk keluar dari aplikasi.

\subsubsection{Perancangan Antarmuka Aplikasi}

\section{a. Halaman Utama}

Halaman utama untuk pengguna dengan status admin akan diarahkan ke halaman utama dengan menu sebagai berikut:

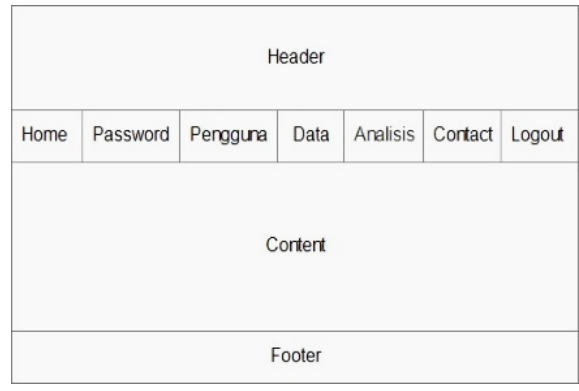

Gambar 4. Form Menu Utama Admin

Untuk user dengan status guru, maka akan diarahkan ke halaman utama dengan menu sebagai berikut:

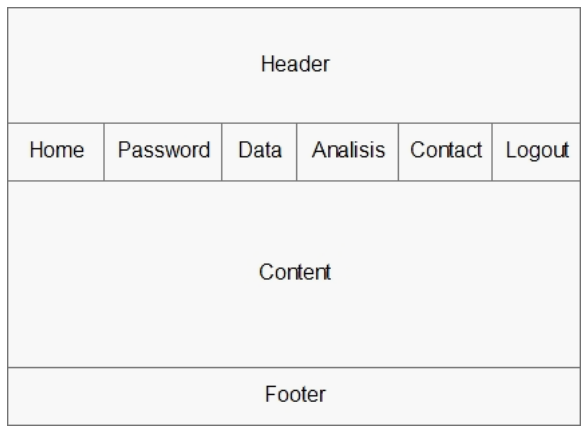

Gambar 5. Form Utama Guru

\section{b. Halaman Data}

Pada Halaman Data, guru dapat menambah data kelas, kompetensi, murid, pelajaran dan soal. Tampilannya adalah sebagai berikut:

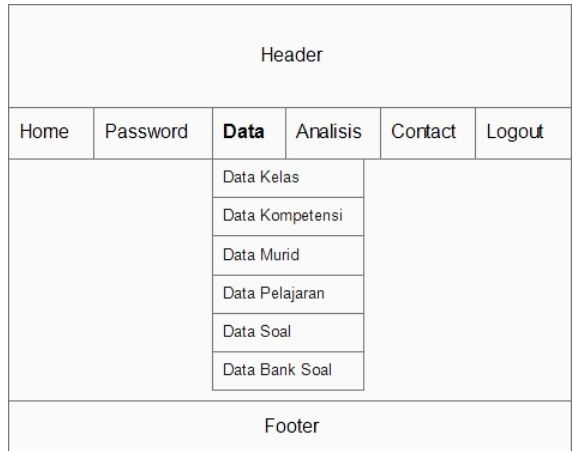

Gambar 6. Form Data

\subsubsection{Perancangan Basis Data}

Contoh perancangan basis data diwakili oleh tabel yang menyimpan data siswa dan daftar kompetensi di sekolah. Perancangan basis data ditunjukkan pada Tabel 1 dan Tabel 2.
Tabel 1. Tabel Kompetensi

\begin{tabular}{|l|l|l|l|}
\hline Field & Type & Key & Keterangan \\
\hline id_kompetensi & int(11) & PK & id kompetensi \\
\hline kode_mp & varchar(3) & & kode pelajaran \\
\hline kompetensi & varchar(30) & & Kompetensi \\
\hline id_kelas & varchar(2) & & id kelas \\
\hline kode_kompetensi & varchar(35) & & kode kompetensi \\
\hline jumlah_soal & int(11) & & jumlah soal \\
\hline status & int(1) & & Status \\
\hline
\end{tabular}

Tabel 2. Tabel Data Siswa

\begin{tabular}{|l|l|l|l|}
\hline Field & Type & Key & Keterangan \\
\hline id_murid & varchar(11) & PK & id murid \\
\hline id_kelas & varchar(2) & & id kelas \\
\hline nama & varchar(100) & & nama murid \\
\hline
\end{tabular}

\section{Hasil dan Pembahasan}

Berdasarkan perancangan aplikasi analisis butir soal, secara garis besar aplikasi ini mempunyai dua tipe user, yaitu Admin dan Guru. Pada aplikasi ini, admin hanya dapat melakukan proses menambahkan dan menghapus data pengguna. Sedangkan guru dapat menjalankan proses menambahkan, menghapus, mengubah data-data siswa, soal, kompetensi, serta menjalankan analisis butir soal dan mencetaknya.

\subsection{Hasil Tampilan}

Tampilan awal dari sistem aplikasi ini adalah menu login, proses login dilakukan oleh user, yaitu admin dan guru. Proses login dilakukan dengan memasukkan email dan password. Saat proses login berhasil maka, halaman yang akan tampil selanjutnya adalah halaman menu utama, halaman ini merupakan form induk dari aplikasi analisis butir soal. Pada form menu utama terdapat beberapa menu yaitu : About, Password, Data, Analisis, Contact, dan Logout (Gb.7).

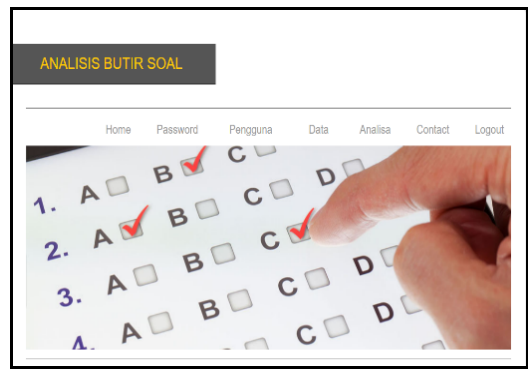

Gambar 7. Tampilan Halaman Menu Utama

Gambar 8 dan 9 menunjukkan tampilan antarmuka halaman Data Kelas dan Data Pelajaran. Pada tiap halaman dilengkapi dengan pilihan untuk menambah data, menghapus, dan menyimpan. Hal yang sama berlaku untuk halaman Data Siswa, Data Kompetensi, dan Data Soal (Gb.10). 


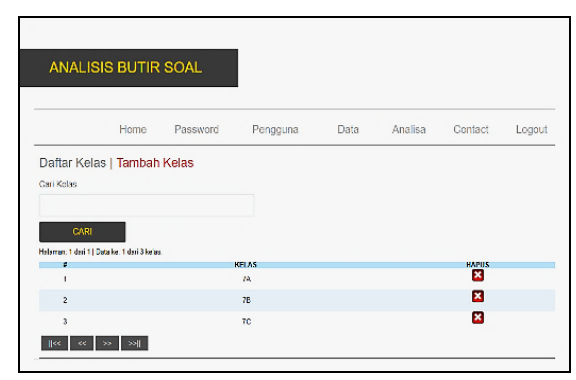

Gambar 8. Tampilan Form Data Kelas

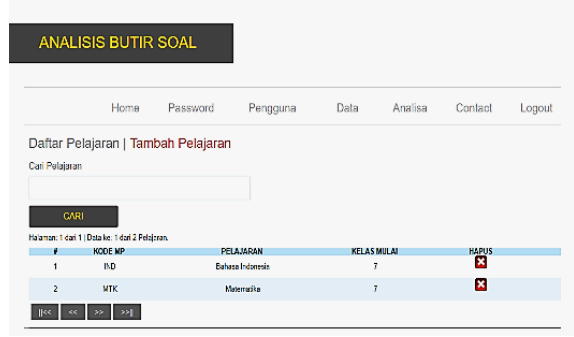

Gambar 9. Tampilan Form Data Pelajaran

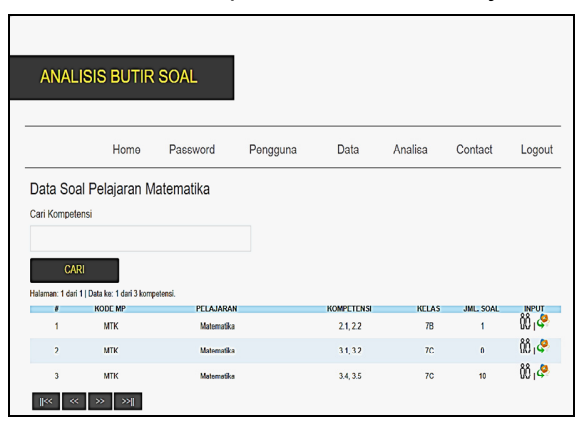

Gambar 10. Tampilan Form Data Soal

Gambar 11 menampilkan halaman Data Bank Soal yang berisi soal-soal yang diterima. Sedangkan gambar 12 menunjukkan halaman Hasil Analisis Butir Soal. Pada menu ini, guru dapat melihat hasil analisis butir soal dengan mengolah data terlebih dahulu seperti data kelas, data kompetensi, data murid, data pelajaran, data soal. Kemudian mengisikan hasil jawaban murid dari soal yang telah dikerjakan. Ini merupakan proses terpenting, karena untuk mengetahui hasil dari perhitungan data. Pada halaman Hasil Analisis Butir Soal, kolom paling kanan menunjukkan status soal, apakah suatu soal diterima, harus direvisi, atau ditolak.

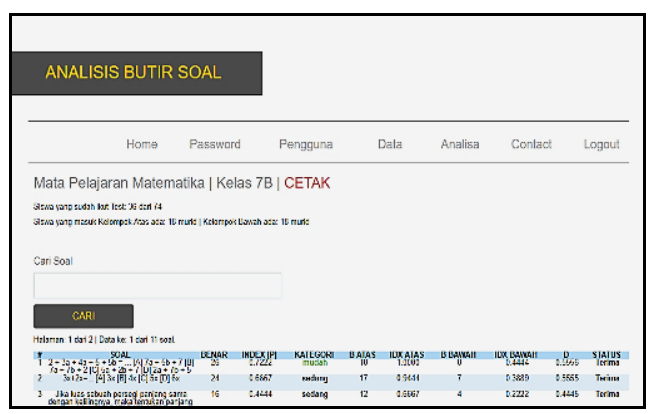

Gambar 11. Tampilan Form Data Bank Soal

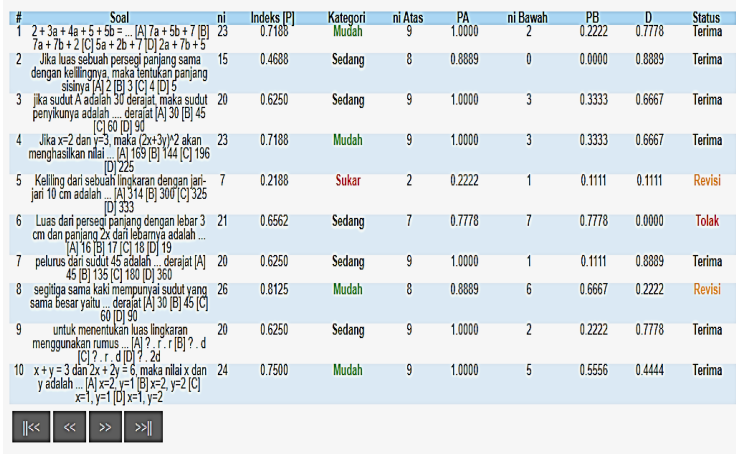

Gambar 12. Tampilan Form Hasil Analisis Butir Soal

\subsection{Pembahasan}

Analisis butir soal dengan pendekatan klasik ini diawali dengan mengurutkan nilai siswa dari nilai tertinggi ke nilai terendah. Tehap selanjutnya adalah dengan mengelompokkan $27 \%$ siswa dengan nilai tertinggi sebagai kelompok atas dan $27 \%$ siswa dengan nilai terendah sebagai kelompok bawah. Baru kemudian dilakukan perhitungan Tingkat Kesukaran dan Daya Pembeda dari masing-masing butir soal. Menurut ahli, pembagian yang paling stabil dan sensitif serta paling banyak digunakan adalah dengan menentukan $27 \%$ kelompok atas dan $27 \%$ kelompok bawah (Surapranata, 2005).

Untuk uji coba, suatu tes Matematika dengan jumlah 10 butir soal diberikan pada 32 siswa kelas 7. Berdasarkan hasil jawaban tes dan perhitungan Tingkat Kesukaran (TK), diketahui bahwa soal nomor 1, 4, 8 dan 10 memiliki indeks kesukaran diatas 0,7 sehingga kategori indeks kesukaran soal adalah mudah. Sedangkan soal nomor 2, 3, 6, 7 dan 9 memiliki indeks kesukaran lebih kecil atau sama dengan 0,7 dan lebih besar dari 0,3 sehingga kategori indeks kesukaran soal adalah sedang. Dan soal nomor 5 memiliki indeks kesukaran lebih kecil atau sama dengan 0,3 sehingga kategori indeks kesukaran adalah sukar.

Butir soal yang memiliki indeks kesukaran tergolong mudah bukan berarti soal tersebut baik untuk digunakan. Begitu pula dengan butir soal dengan kategori sukar bukan berarti bahwa butir soal tersebut tidak boleh dipakai. Pemakaian butir soal tersebut disesuaikan dengan kondisi peserta didik yang akan mengikuti tes. Contohnya, untuk mengetahui hasil belajar siswa pandai sebaiknya digunakan butir soal yang memiliki indeks kesukaran dengan kategori sukar. Demikian pula sebaliknya.

Setelah perhitungan Tingkat Kesukaran, penentuan kelompok atas serta kelompok bawah dilakukan dan diperoleh tabel seperti pada tabel 3 dan tabel 4. Dari 32 anak peserta tes diperoleh 9 anak yang termasuk kelompok atas dan 9 anak termasuk kelompok bawah. 
Tabel 3. Hasil $27 \%$ Kelompok Atas

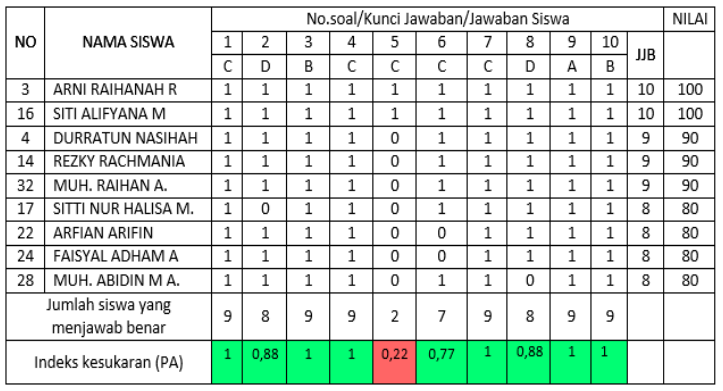

Tabel 4. Hasil $27 \%$ Kelompok Bawah

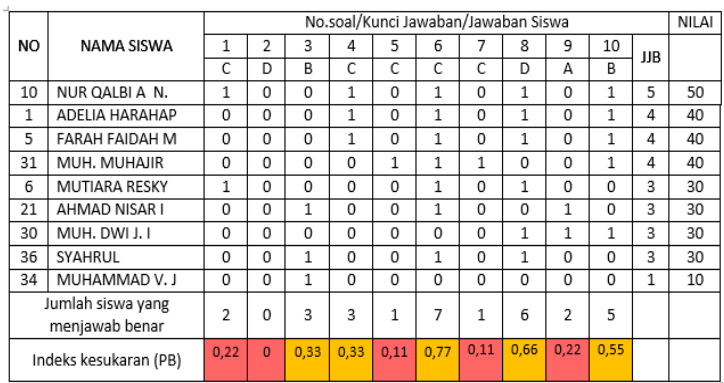

Perhitungan Daya Pembeda (DP) diperoleh dengan menghitung selisih antara jumlah jawaban benar kelompok atas dengan jumlah jawaban benar kelompok bawah, dikali 2, dibagi dengan jumlah total peserta tes. Hasil perhitungan DP menghasilkan tabel 5 berikut.

Tabel 5. Hasil Perhitungan Daya Pembeda

\begin{tabular}{|c|c|c|c|c|c|c|c|c|c|c|}
\hline No & 1 & 2 & 3 & 4 & 5 & 6 & 7 & 8 & 9 & 10 \\
\hline PA & 1 & 0,88 & 1 & 1 & 0,22 & 0,77 & 1 & 0,88 & 1 & 1 \\
\hline PB & 0,22 & 0 & 0,33 & 0,33 & 0,11 & 0,77 & 0,11 & 0,66 & 0,22 & 0,44 \\
\hline D = PA-PB & 0,77 & 0,88 & 0,66 & 0,66 & 0,11 & 0 & 0,88 & 0,22 & 0,77 & 0,44 \\
\hline Status Soal & TR & TR & TR & TR & RV & TL & TR & RV & TR & TR \\
\hline
\end{tabular}

Berdasarkan indeks daya pembeda, hanya soal nomor 1, 2, 3, 4, 7, 9 dan10 yang memiliki indeks daya pembeda lebih besar dari 0,25 sehingga status soal diterima. Soal nomor 5 dan 8 memiliki indeks daya pembeda lebih kecil atau sama dengan 0,25 dan lebih besar dari 0 sehingga status soal perlu direvisi. Butir soal tes memiliki indeks daya pembeda baik yang bernilai positif. Artinya soal tersebut dapat membedakan siswa yang berkemampuan tinggi dan siswa yang berkemampuan rendah. Sedangkan soal nomor 6 memiliki indeks daya pembeda sama dengan 0 sehingga status soal ditolak.

Soal yang memiliki indeks daya pembeda negatif tidak dapat membedakan siswa yang berkemampuan tinggi dengan siswa yang berkemampuan rendah. Butir soal yang memiliki indeks daya pembeda bernilai negatif menunjukkan siswa yang menjawab benar butir soal tersebut memiliki skor yang relatif rendah atau dengan kata lain siswa yang memiliki skor relatif tinggi tidak mampu menjawab butir soal tersebut. Dapat dikatakan butir soal tersebut tidak dapat membedakan siswa yang pandai dan siswa yang kurang pandai. Semakin tinggi indeks daya pembeda soal (bernilai positif) maka semakin baik soal tersebut.

Berdasarkan pengujian aplikasi menggunakan tes Matematika dengan 10 soal pada siswa kelas 7A, 7B, 7C,7E, 7F, dan 7G di SMP Negeri 10 Makassar diperoleh jumlsh hasil butir soal diterima, revisi atau ditolak sebagai berikut:

Tabel 6. Hasil Pengujian Aplikasi

\begin{tabular}{|c|c|c|c|c|c|}
\hline $\begin{array}{c}\text { Uji } \\
\text { ke- }\end{array}$ & Kelas & $\begin{array}{c}\text { Jumlah } \\
\text { siswa }\end{array}$ & $\begin{array}{c}\text { Jumlah siswa yang } \\
\text { mengikuti tes }\end{array}$ & $\begin{array}{c}\text { Jumlah } \\
\text { soal }\end{array}$ & $\begin{array}{c}\text { Jumlah soal } \\
\text { yang } \\
\text { diterima }\end{array}$ \\
\hline 1 & $7 \mathrm{~A}$ & 40 & 38 & 10 & 6 \\
\hline 2 & $7 \mathrm{~B}$ & 35 & 32 & 10 & 7 \\
\hline 3 & $7 \mathrm{C}$ & 38 & 32 & 10 & 6 \\
\hline 4 & $7 \mathrm{E}$ & 32 & 30 & 10 & 5 \\
\hline 5 & $7 \mathrm{~F}$ & 37 & 35 & 10 & 8 \\
\hline 6 & $7 \mathrm{G}$ & 39 & 35 & 10 & 9 \\
\hline
\end{tabular}

\section{KESIMPULAN DAN SARAN}

Berdasarkan hasil penelitian dan pembahasan yang telah dilakukan dapat diambil beberapa kesimpulan, antara lain:

1. Pendekatan klasik dapat mengkategorikan butir soal yang mudah, sedang atau sukar berdasarkan tingkat kesukaran soal serta mengklasifikasikan soal mana yang diterima, direvisi atau ditolak berdasarkan daya pembeda soal.

2. Aplikasi analisis butir soal dengan pendekatan klasik digunakan untuk mempermudah guru di SMP Negeri 10 Makassar dalam melakukan kegiatan analisis butir soal sehingga hasil dari analisis butir soal dapat dijadikan sebagai evaluasi dalam penyusunan butir soal yang berkualitas.

3. Perancangan aplikasi analisis butir soal dengan pendekatan klasik dimulai dengan mengurutkan nilai tertinggi ke nilai terendah, mengelompokkan siswa kelompok atas dan kelompok bawah, menghitung tingkat kesukaran butir soal dan menghitung daya pembeda soal.

Dari hasil penelitian terdapat beberapa hal yang ingin disarankan untuk pengembangan aplikasi ini, yaitu:

1. Aplikasi analisis butir soal ini dapat dikembangkan dengan menambah perhitungan dari bagian pendekatan klasik yang lain misalnya, penyebaran (distribusi) jawaban dan reabilitas skor tes.

2. Aplikasi ini juga dapat dikembangkan dalam jenis soal yang dapat dianalisis, sehingga tidak hanya jenis soal pilihan ganda saja yang dapat dianalisis tapi bisa juga jenis soal esai. 


\section{DAFTAR PUSTAKA}

1. Aiken, L.R. (1994). Psychological Testing and Assesment. Boston: Allyn and Bacon.

2. Anastasi, A. \& S. Urbina. (1997). Psychological Testing. New Jersey: Prentice Hall Inc.

3. Ariyana, L.T. (2011). Analisis Butir Soal Ulangan Akhir Semester Gasal IPA Kelas IX SMP di Grobogan, 1-142.

4. Crocker, L. \& J. Algina. (1986). Introduction to Classical and Modern Test: Theory. NewYork: Holt, Rinehart, and Winston Inc.

5. Fook, C.Y., et al. (2014). Effective Criteria of Item Analysis Software: Introducing SuperSeTIA. $200146^{\text {th }}$ IEEE International Conference on Engineering Education. p: 991-4.

6. Gajjar, S. dkk. (2014). Item and Test Analysis to Identify Quality Multiple Choice Questions (MCQs) from an Assessment of Medical Students of Ahmedabad, Gujarat. Indian Journal of Community Medicine, vol.39, issues 1, January 2014, p.17-21.
7. Nitko, A.J. (1996). Edcational Assesment of Students. Ohio: Merril an imprint of Prentice Hall Englewood Cliffs.

8. Pamilu, A.F. (2014). Analisis Butir Soal pada Ulangan Akhir Semester Gasal Mata Pelajaran Aqidah Akhlaq Kelas X MAN Yogyakarta III Tahun Pelajaran 2013/2014. 1-129.

9. Rogelberg, S. G. (2008). Handbook of Research Methods in Industrial and Organizational Psychology. Blackwell Publishing Ltd.

10. Shuiping, C. and Z. Tingting. (2016). The Application of Computer Statistics Software in the Research on Kindergarten Teachers' Organizational Identification. $2016 \quad 11^{\text {th }}$ International Conference on Computer Science and Education (ICCSE).

11. Subali, B. (2014). Analisis Soal Baik Kualitatif Maupun Kuantitatif. Materi Workshop Item Development Dosen Poltekes Kebidanan Politeknik Kesehatan Surakarta.

12. Surapranata, S. (2004). Analisis, Validitas, Reliabilitas dan Interpretasi Hasil Tes. Bandung: Rosdakarya. 